\title{
Therapeutic Workshops and social changes in people with mental
} disorders

\author{
Oficinas Terapêuticas e as mudanças sociais em pacientes com transtorno mental \\ Talleres terapéuticos y los cambios sociales en pacientes con trastorno mental
}

Aline Raquel de Sousa Ibiapina ${ }^{1}$ Claudete Ferreira de Souza Monteiro ${ }^{1}$ Delmo de Carvalho Alencar ${ }^{1}$ Márcia Astrês Fernandes ${ }^{1}$ Antonio Alberto Ibiapina Costa Filho ${ }^{1}$

1. Federal University of Piauí. Teresina, Piauí, Brazil.

\section{Corresponding Author:}

Delmo de Carvalho Alencar

E-mail: delmo-carvalho@hotmail.com

Submitted on $12 / 18 / 2016$.

Accepted on 03/15/2017.

DOI: 10.1590/2177-9465-EAN-2016-0375

\section{Abstract}

Objective: To analyze the impact of the therapeutic workshops and the social changes in people with mental disorders from the point of view of the experience of the workers of a Center of Psychosocial Attention. Methods: A descriptive, qualitative study developed with seven professionals from a Psychosocial Care Center in a city in the Northeast of Brazil. The data production was performed through a semi-structured interview and analyzed by the Descending Hierarchical Classification, after processing in the IRaMuTeQ software. Results: Were presented in two segments: the first one portrays the reality of the work of the professionals in the Center for Psychosocial Care, while segment two emphasizes the professionals' perception about the therapeutic workshops as a tool for social reintegration. Conclusion: The use of therapeutic workshops contributes to the effectuation of social change on mental illness and social inclusion of people with psychic disorders in the daily family, in the community, encouraged by the multidisciplinary approach.

Keywords: Mental health services; Psychotherapy, Group; Rehabilitation.

\section{Resumo}

Objetivo: Analisar o impacto das oficinas terapêuticas e as mudanças sociais em pessoas com transtornos mentais sob a ótica da vivência dos trabalhadores de um Centro de Atenção Psicossocial. Métodos: Estudo descritivo, qualitativo, desenvolvido com sete profissionais de um Centro de Atenção Psicossocial de uma cidade do Nordeste do Brasil. A produção dos dados foi realizada por meio de entrevista semiestruturada e analisada pela Classificação Hierárquica Descendente, após processamento no software IRaMuTeQ. Resultados: Foram apresentados em dois segmentos: o primeiro retrata a realidade do trabalho dos profissionais no Centro de Atenção Psicossocial, enquanto o segmento dois ressalta a percepção dos profissionais acerca das oficinas terapêuticas como instrumento de reinserção social. Conclusão: A utilização das oficinas terapêuticas contribui para a efetivação da mudança social acerca da doença mental e para inclusão social de pessoas com transtornos psíquicos no cotidiano familiar, na comunidade, incentivadas pela abordagem multidisciplinar.

Palavras-chave: Serviços de saúde mental; Psicoterapia de Grupo; Reabilitação.

\section{REsumen}

Objetivo: Analizar el impacto de los talleres terapéuticos y los cambios sociales en las personas con trastornos mentales desde la perspectiva de vida de los trabajadores en un Centro de Atención Psicosocial. Métodos: Un estudio cualitativo descriptivo desarrollado con siete profesionales de un Centro de Atención Psicosocial de una ciudad en el noreste de Brasil. La producción de los datos se realizó a través de entrevistas semiestructuradas y analizados por Clasificación Jerárquica Descendente, después de su transformación en el software IRaMuTeQ. Resultados: Foram apresentados em dois segmentos: o primeiro retrata a realidade do trabalho dos profissionais no Centro de Atenção Psicossocial, enquanto o segundo segmento expõe a percepção dos profissionais acerca das oficinas terapêuticas como instrumento de reinserção social. Conclusión: El uso de seminarios terapéuticos contribuye a la realización de los cambios sociales en la salud mental y la inclusión social de las personas con trastornos mentales en la vida familiar, comunitaria, animado por el enfoque multidisciplinario.

Palabras clave: Servicios de salud Mental; Psicoterapia de Grupo; Rehabilitación. 


\section{INTRODUCTION}

The Center of Psychosocial Attention (CPSA) is a substitute service to the Psychiatric Hospital that represents the reorientation of the model of attention in mental health from a hospital-centered way for the psychosocial rehabilitation, with a view to promoting the exercise of citizenship. Among the treatment strategies offered in the CPSA, there are the activities of Therapeutic Workshops, which represent an important tool for resocialization and individual and collective insertion, in that it enables the work, the action and the collective thinking, based on a logic of respect for diversity and subjectivity, and for stimulating the capacity of each person. ${ }^{1}$

From this point of view, it is understood that the interaction of the professional with the person who has with mental disorder is a primordial element of care in Nursing practice, because it is through this that a relationship is formed with the cared person and its family, making possible to understand their needs and assist them. The relevance of this study is in the fact that it can help professionals working in the area of mental health, particularly nurses, to qualify the care offered through therapeutic workshops, in the sense of being, knowing and doing in a creative, welcoming and facilitator way for the promotion of mental health. ${ }^{2}$

It should be emphasized that the therapeutic workshops, as strategies of the current National Mental Health Policy aim to differentiate in relation to their predecessor practices and also point to the need for a diversified performance of the multidisciplinary team. Thus, instead of labeling the subject who suffers from a pathology, it is proposed that through listening, there is the possibility of the individual sharing their experiences and feelings and of realizing that the health professional can contribute to their psychosocial rehabilitation. ${ }^{3}$

The therapeutic workshops have been distinguished by the creation of new forms of reception, coexistence, mediations of dialogue and accompaniment that associates the clinic with politics. However, its purposes have suffered modifications throughout history. The earliest reports of its use as a way of rehabilitating subjects date back to the seventeenth century, when hospitals were not yet recognized as health care institutions because they had lay care rather than medical care for "socially maladjusted groups". In this context, the purpose of the activity was, through labor, to restore or maintain social order. ${ }^{4}$

After the inauguration of psychiatry as a medical field and according to the different theories about "insanity", other purposes were conferred to this activity, such as moral treatment, occupation, entertainment and income generation for the maintenance of similar institutions. It is important to emphasize that the idea of adopting work as a therapeutic resource remained in all of them. ${ }^{5}$

Nowadays, in addition to functioning as one of the organizers of daily mental health services, the workshops have been understood as spaces for the production and management of subjectivity, for the reconstruction of bonds between the suffering individuals and their social groups, in addition to meeting the speeches of those who care and receive the care.

Based on the above, it was chosen as the objective of the study to analyze the impact of therapeutic workshops and social changes in people with mental disorders from the point of view of the experience of the workers of a Center of Psychosocial Attention.

\section{METHODS}

A descriptive study with a qualitative approach, conducted with professionals who perform mental health activities in the municipality of Fronteiras-PI, Northeastern region of Brazil. The data collection took place from November to December 2014, through individual interview with seven professionals who carry out activities in the therapeutic workshops with users of a Center of Psychosocial Attention - CPSA I.

To produce the data, a semi-structured interview script was used, with questions related to the development of therapeutic workshops within the Psychosocial Care Center. First, there was a scheduled meeting to explain the objectives and purposes of the interview to the possible participants, and in a second moment, the interviews and statements of the participants of the research were recorded in audio equipment (MP4). Each interview lasted 45 minutes, on average, and only the researcher was present with the interviewee. After data collection, the interviews were transcribed in full and reorganized appropriately for processing.

In this study, the Descending Hierarchical Classification (DHC) was used to describe the classes. Thus, the DHC based on the algorithm proposed for the Alceste software by Reiner, and lexical analysis, provides contexts and classes of discourses characterized by their vocabularies. The generated classes represent the sense environment of the words and can indicate social representations or elements of social representations referring to the studied social object. ${ }^{6}$

The IRAMUTEC software (Interface de R pour lês Analyses Multidimensionnelles de Textes et de Questionnaires) was defined as the Descending Hierarchical Classification (DHC) method for analysis, where the texts are classified according to their respective vocabularies and a group of them is divided by the occurrence of reduced forms. IRAMUTEQ enables different types of analysis, from simple to multivariate, such as DHC. The software, to perform classic lexical analysis, identifies and reformats the text units, which are transformed from the Initial Context Units (ICU) into Elementary Context Units (ECU). ${ }^{7}$

The study was registered in the Brazil Platform under the number of the Certificate of Presentation for Ethical Appreciation (CAAE in Portuguese): 34827514.2.0000.5214, and approved under the opinion: 874958.

\section{RESULTS AND DISCUSSION}

Concerning the socio-demographic characterization of the participants, there was a greater female presence in the 
multiprofessional team, and the age groups were distributed between 24 and 66 years, most of them coming from Frontiers$\mathrm{PI}$. According to the professional training, two of them had a technical level, five had a higher education level, of which four had lato sensu specialization -two in Mental Health, one in Family Health and one in Social Project Management, only one had no specialization. The duration of vocational training ranged from two to 41 years. As for the time of professional performance in the CPSA I, it was possible to verify that the participants worked on average of 5 months to 1 year and among them, only one worked in another psychiatric institution.

After submitting the statements to the processing, the software recognized the separation of the corpus in 69 Units of Elementary Context, from six Units of Initial Context, with occurrences of 2,876 words and use of $83.13 \%$.

The divisions and subdivisions suffered by the corpus gave rise to two segments or axes. The first segment was subdivided rising the classes 7, 5, 3 and 4, linked to the Professional's
Perception about the socio-therapeutic activities. A second ramification, originated the classes 1,2 and 6, linked to the use of therapeutic workshops as a rescue of the CPSA user.

The spatial distribution of the most relevant classes and words can be observed in the dendogram (Figure 1).

\section{The classes and their meanings}

Class 7: Professional Motivation for Work at CPSA

From the professionals' speeches, it was possible to understand their perceptions about the choice of work in the CPSA, the curiosity on mental health area and the importance of this choice. In these perceptions, a sense for the transformation of the individual into psychic suffering and their readaptation in society is observed.

I chose to work in the CPSA because I was very curious to work with people who have mental problems, because they are that kind of people we treat with great affection and they become very attached to us. (Dep. 02)

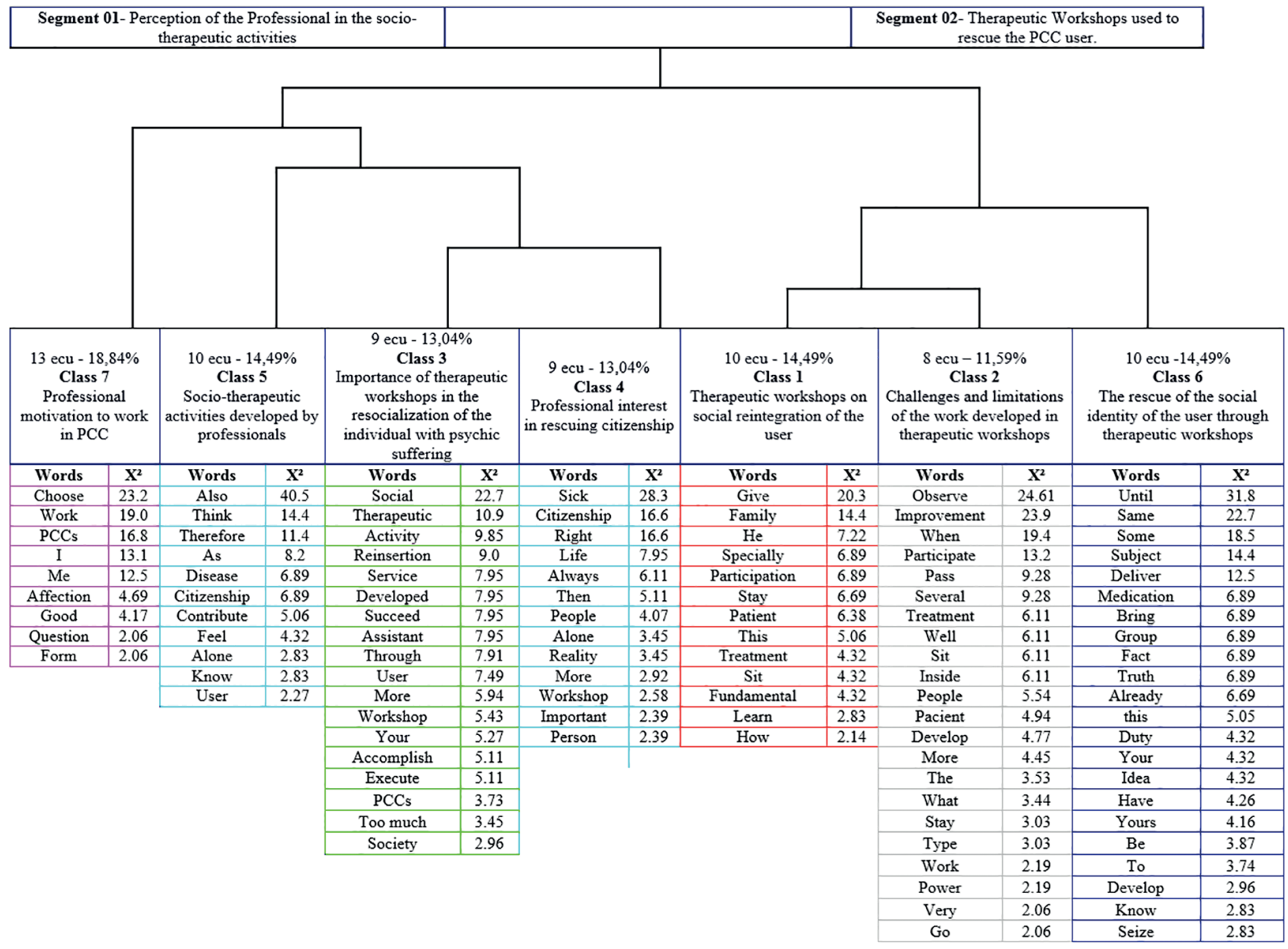

Figure 1. Dendogram of the classes obtained from the corpus. Fronteiras-PI, 2014. 
For me, working in CPSA is very important, very good. (Dep. 03)

\section{[...] I think the CPSA chose me and then I chose it because I started to fall in love with the work process it introduced me so that I could and was contributing to the reintegration of these people with problems in the community. (Dep. 06)}

The reflection and construction of professional thinking during the speeches show that the professional choice was motivated initially by curiosity and later by the personal satisfaction of working with people in psychic suffering, considering them needy people with necessities for dialogue, attention and care.

It is also noticed in the participants' reports that the therapeutic process presented by the CPSA was stimulating for the professional to develop a work that could contribute to the reinsertion of the individual into psychological suffering in society.

The feeling of appreciation and recognition of the work, allows the construction of creative arrangements in the development of workshops within the CPSA. Thus, the Brazilian psychiatric reform points to a transformative action of knowledge in psychiatry in which this transformation, in many moments, is experienced by the CPSA worker as a pleasure factor. ${ }^{8}$

Class 5: Socio-therapeutic activities developed by professionals

In the context of the CPSA, the professionals are oriented to develop activities with various resources seeking to break with the biomedical model, to reinsert the user in society and to rehabilitate it. For this, therapeutic support activities that should always count on the support of the family and the community are used.

I work there with the materials that are available in the institution; in fact, it is very rare to lack material here for the activities of therapeutic workshops. I usually work with paintings. (Dep. 02)

Therefore, through artistic products like rugs, custom made flip-flops, I think that the user is reinserted as a worker, as a student, as a human being and as a citizen who knows, who studies (Dep. 06).

In the interviews, the professionals mentioned the lack of financial resources to carry out various activities of workshops, since it is observed that in the municipality there is not enough investment for the mental health activities, resulting in an impoverishment of these activities and delaying in a certain way the rescue and the autonomy of this individual.

Painting activities are the ones that happen most daily in the CPSA routine, since these activities serve to benefit the emotional balance of each individual, facilitating the expression and overcoming of blockages, occupation of the mind, fears, insecurities and maintaining a healthier relationship with themselves and with others, as well as fortifying a better elevation of self-esteem. It was also possible to observe that in one of the speeches of the professionals who make use of the making of objects as a form of treatment for patients, such as for example rugs and custom made flip-flops.

The diversification of activities is essential to realize the users' reception in an integral way, since, with varied and diversified offerings of possibilities, the temptation of the selection is greatly reduced. ${ }^{9}$ In this sense, the workshops allow the conquest or (re)conquest of users in relation to their interaction in society with autonomy and recognition of a citizen. This work requires assistance from the family, since the user must feel supported to produce connections between the various components of daily life, such as work, leisure, friends, reflecting on the credibility and maturation of the own family in this process. ${ }^{8,9}$

Class 3: The role of therapeutic workshops in the resocialization of the individual with psychic suffering

Therapeutic workshops are aimed at individuals with psychic suffering, becoming a key piece for resocialization, while allowing the development of actions and group work, acting and thinking collectively in order to comply with the psychosocial proposal that maintains a focus on respecting the differences and the individuality of each participant.

The idea of the therapeutic workshop is to make the user to identify itself with that activity, that he/she is able to perform that activity, that feels useful as a human being, useful as a person, useful as a user of the service of the CPSA. (Dep. 04)

Therapeutic workshops enable their social reinsertion into society and offer the best for them through these activities. (Dep. 07)

The discourses strengthen the conception that therapeutic workshops are indispensable tools in a process of resocialization of individuals with psychic disorders, providing them not only an ability to perform activities, but mainly for exercising and helping them to put into practice their internal desires. This makes him/ her feel useful in carrying out his/hers activities in order to make them aware of their abilities and potentialities, since these activities end up being overcome by treated individuals, favoring interaction with the social environment and helping them in their resocialization, having an allied treatment with the professionals' support, medicines and participation in the activities developed within the service.

In order to be effective in the process of social resocialization, the actions of the workshops are delimited by the interpersonal relationships between professionals, users and community, being the proper work a form of resocialization because it deals directly with communication and the interrelationships between persons who occupy the service. ${ }^{9}$

The importance of participating in therapeutic workshops for treatment was highlighted by CPSA users in an investigation. 
They pointed out a variety of activities in the therapeutic workshops that can be configured as a tool to help in the reorganization of their lives. ${ }^{10}$

The therapeutic workshops make the care at the CPSA pleasant, promoting in addition to the treatment the socialization among the participants and the development of activities, as in the beauty and culinary workshops. Workspaces such as these, in addition to being therapeutic, encourage users to develop these actions not only in the CPSA, but also in their homes, contributing to the exercise of autonomy in their daily lives. ${ }^{10}$

The process of rehabilitation can be understood as a consequence of the exercise of established citizenship through the treatment and resocialization of CPSA users. The workshops are intended to provide the simulation and accomplishment of this exercise when interacting with other people. This exercise requires dialogue, understanding and empathetic of what is said, characterizing relational aspects of people's rehabilitation process. ${ }^{11}$

Class 4: Professional interest in rescuing citizenship

As for the aspects that define the therapeutic workshops, one of the primordial characteristics is its opportunity to provide reflection, dialogues, interactions and the building of bonds between people, so that there is a rescue of sociability and citizenship through the exercise of the rapprochement between the different actors who attend in CPSA. This mission of the professional with the user is related to a good capacity and availability of the same to interact with the mentally ill and to perform their attributions that are advocated by the psychiatric reform, respecting the humanized model of treatment.

It is verified that professionals are concerned with the approximation between users and their applied techniques, aiming at an interaction from the treatment environment. In this sense, health professionals related the importance of the rights of people with psychiatric disorders, as a basis for their coexistence in society, as well as the guarantee to the exercise of their citizenship.

Therapeutic workshops are important because they potentiate dialogical exchanges. These new approaches are an attempt to understand mental disorders in a different way, with emphasis on the sick person, in their way of life, in the reality in which they are inserted. (Dep. 07)

My line of work is precisely the citizenship. To explain to them the right of the elderly, of the mentally ill, of the physically disabled. They always read the briefing. My part of the workshop is more focused on the question of reinserting them into the community. (Dep. 06)

My work is more focused on the right and social reintegration, to be prevailed. I see that the therapeutic workshops are important in the life of the mentally ill; because I see it contributes to their environment. (Dep. 04)
In the speeches mentioned above, the potential of the therapeutic workshop by the acting professionals is recognized as a primary factor of the user's treatment in the CPSA, with the objective of providing a better psychosocial rehabilitation, through dialogic exchanges, sharing of experiences and progress in adapting both individual and group life in the reality in which they are inserted, because they are necessary tools for the internalization of meanings relevant to their life.

In general, the therapeutic group allows the sharing of experiences among the participants, providing listening, guidance and construction of therapeutic projects that are in keeping with the subjects' needs. At the same time, the group experience favors a greater problem-solving capacity, since it has several points directed towards a common problem. This experience leads to the construction of new visions and senses capable of providing significant changes in the perception of life of its members. ${ }^{11}$

Class 1: The role of therapeutic workshops in the social reinsertion of the user

The therapeutic workshops have a great contribution to the productive therapeutic process and integral development of the subject's capacity, also offering possibilities to eliminate or minimize the forms of exclusion in the society and causing that the satisfaction of the needs of the participants occurs through the relation with the other.

The concern of professionals in the development of a quality work aimed at social reintegration is highlighted in the following reports:

Because it is the type of open treatment in which the patient is not treated in insane asylum institution and understood that he/she will have a proper social reinsertion condition, mainly because he/she must be treated by a multi-professional team and I give much value to this. (Dep. 03)

This reinsertion is given through their participation in workshops, they learn to paint, to make drawings, frame collages, cut and seams, we also work with biscuits and many other activities. (Dep. 02)

This is where we are most grateful to be contributing positively to the treatment of that patient, as well as they express their joy in the development and participation of the activities in which we develop in the CPSA for their families. (Dep. 05)

The relationships within therapeutic workshops need to be well established, in order to leave the user free to express their desires and concerns, their art needs to be valued and the professional cannot stop promoting freedom of expression, providing a service free of impositions.

It can be said that the professionals who guide the activities of the workshops contribute with the users in the construction of life forms. However, as with any job, the workshops have limits. Many times, users do not feel comfortable to expose experiences 
and feelings to the group, which leads to the need to maintain individual care alternatives. Difficulties also arise when the bonds are fragile, when there is no trust in the professionals, in the other participants or in oneself. The entrance of each participant in the workshops, their departure or their return express characteristics of their ties with the CPSA and with the professionals; also express peculiarities of the moment of the treatment of each one and of his/hers situation of life. The treatment is certainly not univocal and simple. The time and choice of each may vary. Participation in the workshop contemplates many users, but it is not the only option for everyone. ${ }^{12}$

Deinstitutionalization needs to take place effectively, because even in a non-enclosed environment, what needs to be changed is the team's attitude, the preparation and naturalness with which the patient is cared for and the responsibility that everyone assumes before that being in the process of returning to the social environment, respecting all the particularities of the daily life of each user and working in an integrated way so that the patient has access to holistic care.

The essence of a multi-professional work is to cure any type of difficulty established in the treatment, because from the different look of each professional it is understood that the user will be more likely to be approached in their difficulties.

As for the aspects that deal with the role of therapeutic workshops in the social reintegration of users, it is verified that professionals report proposed activities that corroborate with the specific literature on the subject. The established perception encompasses activities that seek to deconstruct a psychiatric structure in its obsolete form of existence, for the construction of a new model, focused on care and concern for users' rights. ${ }^{13}$

Class 2: Challenges and limitations of the work developed in therapeutic workshops

The professionals' perception about the challenges and limitations of the work developed in the therapeutic workshops was identified. It is essential that professionals have the ability to promote interaction and exploration in moments of dialogic exchange during the activities.

With regard to social reintegration, it was noted that it is necessary to advance much more in the overcoming of the biomedical model within the CPSA, since it was observed in the participants' speeches that the doctors did not participate in the activities of therapeutic workshops, leaving it to the care of other professionals.

These activities have the participation of all the patients along with the professionals present, with the exception of the doctor who only attends and prescribes the medication [...]. (Dep. 02)

I sincerely never directly participated at this part because my function, due to being only me as a psychiatrist in a micro and macro region has no way, but l agree with these workshops within CPSA. (Dep. 03)
In this sense, it is evident the lack of professional specialized in psychiatry or the disinterest of the municipal manager in hiring other specialized professionals, causing a constant overload of the psychiatric doctor's agenda in the micro region.

It is also observed that the time dedicated by the professional is short to participate in the activities of workshops, as the inexistence of this professional in these activities can compromise and delay the deinstitutionalization of this user of the CPSA. In fact, it was identified in the speech that the presence of the doctor in this service is restricted to individual care and prescription of medications, and this has evidenced in a certain way, the inefficiency of an integrated care.

It is possible to say that the hospital-centered model remains rooted in the medical philosophy that agrees with the therapeutic rehabilitation. However, it continues to be based on the drug treatment as primordial and leaves the other professionals in charge of the other activities, being restricted only to their routine activities, which interferes negatively in the therapeutic result and creates difficulties for the team and the users.

In mental health, the efficient attention is the psychosocial, through which one can transcend the exclusive medicalization of the disease and offer patients spaces of listening, welcoming, interaction and social bond. It cannot be denied that deficiencies in the user-professional link compromise the reception of mental suffering and that the failures in the organization of services reflect the limits of the biomedical model still ingrained and impregnated in established practices. ${ }^{14}$

Class 6: The rescue of the social identity of the user through therapeutic workshops

It is understood that when an individual seeks the treatment offered in the CPSA, he is usually experiencing a moment of great emotional fragility, and as a consequence of this it ends up concentrating and manifesting in his daily actions only the symptoms of the disease, which becomes a focus.

The therapeutic workshop is seen by professionals as a timely tool to channel the user's thoughts and values, leading to the production of something useful for themselves and for the community around them, which can lead to a more effective psychosocial rehabilitation process and to trace a path of interest to this search for the social and active being.

The therapeutic workshop is of fundamental importance to provide a better reintegration of this subject in society. It depends and will depend on the type of therapeutic workshop that you propose, depends on the resources you have to develop. (Dep. 04)

What we do there with them, will enable them to learn and even do at home, to sell to make an advantage for themselves. (Dep. 02)

[...] These workshops allow the patients to express their ideas and feelings, being able to overcome the fear and stigma of being incapable. (Dep. 03) 
A positive response from the treatment developed in the CPSA can be evidenced in the professionals' discourses, since the appropriate workshop is chosen for the user, and that are resources available for usage in these activities. It is worth mentioning that at no time the deponents did not make clear what the necessary resources would be to carry out these activities.

In this sense, the therapeutic workshops provide the rescue of the user's identity after their effective participation in these activities applied within the CPSA. All these impressions are clearly sketched by professionals, as they understand the workshops as work proposals focused on objectives, be it of expression, education or production in which the users manifest themselves in a healthy way, showing their potential to solve problems within the workspace and consequently broadening these attitudes towards their social life.

In this way, the transformation of the person and the elevation of his/her self-esteem happen precisely when he/she can feel him/ herself to be much greater than his/hers illness, that in addition to the manifestation of symptoms and drug treatment, through the workshops he/she can rediscover its usefulness, potentiality to overcome suffering and even learn from it.

A survey carried out in São Paulo brought experiences of income generation workshops and/or cooperatives in the context of mental health. There were several activities developed by the involved ones, such as carpentry, mosaic, sewing, graphic, garden, locksmith, culinary and nutrition, stained glass, candles, sheep farming, civil construction, digital inclusion and video. The authors of the research pointed out, from the experiences studied, a great potential in the Brazilian reality, which further reinforces the commitment of continuity and investment in actions that make possible practices of insertion in work, income generation and social inclusion. ${ }^{15}$

The construction that takes place within the CPSA requires a more individualized approach and these spaces of interaction provide a direct contact with the particularities of each of the patients, as well as the relational involvement of each other and this ends up disseminating the patient's will to relate when perceiving the value given to their productions. ${ }^{16}$

\section{CONCLUSION}

From the study, it was verified that the therapeutic workshops make it possible to articulate and consolidate the policy of the Psychiatric Reform of deinstitutionalization, since there is interest and professional motivation for the work in the CPSA, aiming the transformation of the individual in psychic suffering and its readaptation in society. It was also observed that the accomplishment of socio-therapeutic activities developed by the professionals sought to provide therapeutic support to the patients, in addition to count with the support of the family and the community to perform them. The diversity of activities carried out is essential for the full reception of the users. In this way, the therapeutic workshops are important for resocialization in the sense of configuring a key piece of this process that allows the development of group activities respecting the differences and individualities of each participant.

One of the main characteristics of the workshops was the opportunity to provide reflection, dialogues and building links between people in order to enable a rescue of sociability and citizenship, and it was observed that professionals are concerned to carry out their activities according to what is recommended by the psychiatric reform and respecting the humanized treatment. Thus, the relationships within the workshops are understood by the professionals as having to be established in the sense of leaving the user at ease to manifest their desires and concerns, providing a service free of impositions.

The study evidenced the importance of moving forward with regard to the overcoming of the biomedical model within the CPSA, since it was observed that the absence of the doctors in the participation of the activities of the therapeutic workshops, leaving it to the other professionals, being this a limitation, since it requires the constant presence of a professional specialized in psychiatry.

It is also considered as a limitation of the study the fact of having been interviewed only CPSA professionals. Users and family members were not investigated. Other studies on the same theme are suggested, with investigations targeted to those groups, to know their realities and concrete social changes from the perspective of them.

It was verified that when an individual searches for the treatment offered in the CPSA, it usually is experiencing a moment of great emotional fragility, and ends up concentrating and manifesting in its daily actions only the symptoms of the disease, which becomes a focus.

Therefore, the therapeutic workshop is seen by professionals as a timely tool to channel the thoughts and values of this user, leading to the production of something useful for itself and for the community around them, which may lead to a psychosocial rehabilitation process more effective and draw a path of interest to this search for the social and active being.

\section{REFERENCES}

1. Noronha AA, Folle D, Guimarães AN, Brum MLB, Schneider JF, Motta MGC. Percepções de familiares de adolescentes sobre oficinas terapêuticas em um centro de atenção psicossocial infantil. Rev Gaúcha Enferm [Internet]. 2016; [cited 2017 Jan 22]; 37(4):e56061. Available from: http://www.scielo.br/scielo.php?script=sci_arttext\&pid=S1983 14472016000400402\&Ing=pt\&nrm=iso\&tIng=en. ISSN: 1983-1447 http://dx.doi.org/10.1590/1983-1447.2016.04.56061

2. Souto VT, Terra MG, Soccol KLS, Mostardeiro TS, Xavier MS, Teixeira JKS. Cuidado da equipe de enfermagem na percepção de familiares de pacientes psiquiátricos. Rev Enferm UFPE [Internet]. 2015; [cited 2016 Mar 08]; 9(Suppl. 2):910-17. Available from: http://www.revista.ufpe.br/ revistaenfermagem/index.php/revista/article/view/5980

3. Ministério da Saúde (BR). Saúde mental no SUS: Os Centros de Atenção Psicossocial. Brasília (DF): Ministério da Saúde; 2004 [cited 2017 May 8]; 86p. Available from: http://www.ccs.saude.gov.br/saude_mental/pdf/ sm_sus.pdf

4. Pinho LB, Kantorski LP, Wetzel C, Schwartz E, Lange C, Zillmer JCV. Atividades terapêuticas: compreensão de familiares e profissionais de um centro de atenção psicossocial. Esc Anna Nery [Internet] 2013 Aug; [cited 2015 Sep 10]; 17(3):534-41. Available from: 
http://www.scielo.br/scielo.php?script=sci_arttext\&pid=S141481452013000300534\&lng=en http://dx.doi.org/10.1590/S141481452013000300018

5. Santos EO, Willrich JQ, Meneses BHSR, Franchini B, Antunes B, França SM. Serviços substitutivos na perspectiva da reabilitação psicossocial: um relato de experiência. Ciênc Cuid Saude [Internet]. 2013; [cited 2017 Jan 20]; 11(3):588-92. Available from: http://www. periodicos.uem.br/ojs/index.php/CiencCuidSaude/article/view/15417/ pdf. ISSN: 1984-7513 http://dx.doi.org/10.4025/cienccuidsaude. v11i3.15417

6. Soares RD, Villela JC, Borba LO, Brusamarello T, Maftum MA. O papel da equipe de enfermagem no Caps. Rev Esc Anna Nery [Internet]. 2011; [cited 2015 Sept 10]; 15(1):110-5. Available from: http://www.scielo.br/ scielo.php?script=sci_arttext\&pid=S1414-81452011000100016 http:// dx.doi.org/10.1590/S1414-81452011000100016

7. Camargo BV. ALCESTE: Um programa informático de análise quantitativa de dados textuais. In: Moreira ASP, Camargo BV, Jesuíno JC, Nobrega SM Orgs. Perspectivas teórico-metodológicas em representações sociais. João Pessoa: Editora Universitária UFPB; 2005 p.511-39. Available from: http://www.laccos.com.br/pdf/Camargo2005_ alc.pdf

8. Glanzner $\mathrm{CH}$, Olschowsky A, Kantorski LP. Work as a source of pleasure: evaluating a Psychosocial Care Center team. Rev Esc Enferm USP [Internet]. 2011 June; [cited 2015 Sep 10]; 45(3):716-21. Available from: http://www.scielo.br/scielo.php?script=sci_arttext\&pid=S008062342011000300024\&lng=en http://dx.doi.org/10.1590/S008062342011000300024

9. Kantorski LP, Coimbra VCC, Demarco DA, Eslabão AD, Nunes CK, Guedes ADC. A importância das atividades de suporte terapêutico para o cuidado em um Centro de Atenção. Rev Enferm Saúde [Internet]. 2011; [cited 2015 Sep 10]; 1 (1):4-13. Available from: http://periodicos. ufpel.edu.br/ojs2/index.php/enfermagem/article/view/3401

10. Nasi C, Schneider JF. The Psychosocial Care Center in the everyday lives of its users. Rev Esc Enferm USP [Internet]. 2011 Oct; [cited 2017 Jan 22]; 45(5):1157-63. Available from: http://www.scielo.br/scielo.
php?script=sci_arttext\&pid=S0080-62342011000500018\&lng=en http://dx.doi.org/10.1590/S0080-62342011000500018

11. Middleton J, Perry KN, Craig A. A Clinical Perspective on the Need for Psychosocial Care Guidelines in Spinal Cord Injury Rehabilitation. Int J Phys Med Rehabil [Internet]. 2014; [cited 2015 Sep 10]; 2(226):1-6. Available from: http://www.omicsonline.org/open-access/a-clinicalperspective-on-the-need-for-psychosocial-care-guidelines-in-spinalcord-injury-rehabilitation-2329-9096.1000226.pdf doi: 10.4172/23299096.1000226

12. Souza LGS, Pinheiro LB. Oficinas terapêuticas em um Centro de Atenção Psicossocial - álcool e drogas. Aletheia [Internet]. 2012; [cited 2015 Apr 30]; 38-39:218-27. Disponível em: http://pepsic.bvsalud.org/ scielo.php?script=sci_arttext\&pid=S1413-03942012000200018

13. Daisyanne SB, Antonio GA, Cinthia MC, Maria SBJ. Cuidado em saúde mental por meio de grupos terapêuticos de um hospital-dia: perspectivas dos trabalhadores de saúde. Interface [Internet]. 2010; [cited 2015 Sep 10]; 14(32):127-38. Available from: http://www.scielo. br/scielo.php?script=sci_arttext\&pid=S1414-32832010000100011 $\mathrm{http}: / / \mathrm{dx}$.doi.org/10.1590/S1414-32832010000100011

14. Ribeiro LA, Marin LL, Silva MTR. Atividades grupais em saúde mental. Rev Baiana Enferm [Internet]. 2014; [cited 2015 Sep 10]; 28(3):283-93. Available from: http://www.portalseer.ufba.br/index.php/ enfermagem/article/viewArticle/9980

15. Lussi IAO, Matsukura TS, Hahn MS. Reabilitação psicossocial: oficinas de geração de renda no contexto da saúde mental. Mundo Saúde [Internet]. 2011; [cited 2015 Apr 30];34(2):284-90. Disponível em: http:// www.saocamilo-sp.br/pdf/mundo_saude/75/284a290.pdf

16. Azevedo DM, Miranda FAN. Oficinas terapêuticas como instrumento de reabilitação psicossocial: percepção de familiares. Esc Anna Nery [Internet]. 2011; [cited 2015 Sep 10]; 15(2):339-45. Available from: http://www.scielo.br/scielo.php?script=sci_arttext\&pid $=$ S1414-81452011000200017 http://dx.doi.org/10.1590/S141481452011000200017 